\title{
FACILITATION IN THE CONTEXT OF PEDAGOGICAL ACTIVITIES
}

\author{
Olena Ogienko \\ Institute for Education Studies \& Adult Education \\ of National Academy of Pedagogical Sciences of Ukraine, Kyiv, Ukraine \\ el.ogienko@gmail.com
}

\begin{abstract}
The article defines pedagogical facilitatiofesn as one of the key factors of teacher's professionalism that includes both personality features (purposefulness, attitudes, relationships, motives and values), and their use in professional activities and communication (individual style of activity, communicative competence, etc.); as an innovative approach to teaching which promotes interest, cognitive activity, consciousness of the learner, realization of personally meaningful goals in the learning process and setting up creative learning environment. Essential characteristics of teacher facilitation are revealed: understanding and support as foundations for the interaction of teacher and learners as also learners with each other, recognition of the right of each participant of the interaction to have his or her own opinion, recognition of each individual as a unique personality, collective responsibility for decision making. The concept of facilitation is analyzed, according to which the algorithm of educational actions of the teacher is presented as an "Attribution ring" which involves the facilitation of motivation activities, goal setting, search of the subject of knowledge, search of learning methods, search of means of knowledge acquisition, realization of the learning process, and reflection. The features of facilitative communication are outlined; the educational action in facilitative interaction is proved to be determined by the psychological safety and psychological freedom as also by the empathy of the teacher, his or her professional and teaching tolerance and communicative competence, congruence, the creation of conditions for facilitative communication and facilitative influence. The psychological factors of educational action in facilitative interaction are identified: the importance of learning for learners; congruence of the teacher; psychological safety and psychological freedom, creation of conditions for facilitative communication.
\end{abstract}

Keywords: facilitation; educational activities; facilitative communication; facilitative interaction; empathy; reflection.

Introduction. The spiritual and national revival of Ukraine is impossible without the comprehensive process of humanization of society which requires significant changes in the educational system, principles of its organization, forms and methods of the educational process. Since the learning process is realized through the interaction of its paticipants - a teacher and a learner, - the study of the pedagogical activities of the teacher is of urgent importance. The pedagogical activities are realized through pedagogical actions, therefore, the development of the active position of the learner and the nature of the interaction between the participants of the learning process depend on the teacher's pedagogical actions. As emphasized by I. Zyazyun (2008), humanistic paradigm appeals to individualization and differentiation of learning, the joy of learning, the process of creativity (p. 156). In that context, the most prevalent became the idea of an individual's great resources for self-cognition and purposeful behavior which can only be realized when the certain climate of facilitative psychological attitudes is created. Professional position of the teacher as facilitator provides an opportunity for engagement of such attributes of an individual's psychics as consciousness, energy, subjectiveness, commitment, motivation in the process of pedagogical interaction.

Analysis of psychological and pedagogical literature shows that the vast majority of pedagogical and psychological studies of educational activities are based on the theoretical positions of B. Ananiev, P. Galperin, N. Kuzmina, A. Leontiev, S. Rubinstein, L. Vygotsky and others. Various aspects of educational activities are studied, including: ways of adaptation, formation of professional and pedagogical culture and proficiency (A. Aleksyuk, I. Bech, E. Barbina, V. Grinyova, N. Kuzmina, A. Nisimchuk, I. Pidlasyy, V. Semychenko, M. Stelmahovych, I. Zyazyun and others), issues of motivation and evaluation of the teachers' performance (L. Chernenko, R. Kyhel, V. Notchenko, G. Skok, V. Zhukov), specific features of pedagogical interaction (O. Dubasenyuk, A. Kovalev, T. Sharuhina, I. Tymchenko, I. Zyazyun, B. Zhytnyk), development of the teachers' professional competence (L. Karpova, V. Lozova, A. Markova, E. Pavlyutenkov) and others.

A variety of systems of educational interaction and their efficiency are considered in historical and social (M. Cole, M. Mead, V. Zinchenko), theoretical and psychological (V. Davydov, G. Kostiuk, S. Maksimenko), psychological and pedagogical (O. Leontiev, V. Kan-Kalyk, C. Rogers, 
Y. Shvalb) contexts. Theoretical foundations of facilitation are substantiated by G. Batyschev, V. Bibler, L. Buyeva, L. Vysheslavtsev and others. But the problem of facilitation still requires further study, especially in the context of pedagogical action.

The article aims to disclose the essence of pedagogical facilitation and the features of facilitative communication in pedagogical activities of the teacher in the context of the development of an individual's ability and aspiration for self-dependence, self-development and self-actualization.

The phenomenon of facilitation. The term "facilitation" came to pedagogy from humanistic psychology and means "assistance", "help", "promotion".

In science, social and pedagogical facilitation are singled out. The terms "social facilitation" and "pedagogical facilitation" differ in their specific impact on people: in the first case facilitation is realized through the observation of the actions of an individual, in the second case it is realized by means of the communication style of the teacher with his or her learners and the impact of his or her personality on the character of the learners.

The development of the concept of pedagogical facilitation was initiated by C. Rogers and other representatives of humanistic psychology in the 1950-s. C. Rogers (1994) perceived facilitation as a type of training in which the teacher as facilitator, taking the position of a partner, promotes both the student's and his or her own growth and development (p. 22).

As evidenced by our research, contemporary scientists view facilitation in different contexts: as a type of educational interaction in which the main goal of the teacher is to create favorable conditions for self-development of the learner (O. Dymova, S. Smyrnov); professionally significant feature of the teacher, which provides for such interaction (O. Dymova); the ability of the teacher to perform facilitative communication as an inherent feature of the teacher's personality (O. Vrublevska, L. Kulykova, V. Sumina); a special kind of the teacher's impact on the learners aimed at assistance, encouragement of their need for development, personal growth $(\mathrm{H}$. Ball, O. Kondrashyhina); a process of enhancement of the efficiency of education and learning as a joint activity of the teacher and the learner (O. Shahmatova, I. Shunina); a professionally significant feature of the teacher's personality which determines the success of educational activities (I. Zhyzhyna, E. Zeyer); the ability of the teacher to establish "facilitating relations" with the learner for the purpose of facilitation of learning (K. Rogers, J. Freiberg, O. Halitsan).

The ideas of the value of an individual and his need for "continuous improvement" are key for the understanding of the essence of facilitation. Therefore, the educational facilitation can be defined as a specific type of pedagogical activities of the teacher which aims to assist the learners in their self-actualization, self-improvement and self-esteem, to maintain their commitment to selfdevelopment, self-improvement, to promote their personal growth, to disclose their capabilities, cognitive abilities, to actualize their axiological attitude to people, nature, national culture based on setting up the atmosphere of unconditional acceptance, understanding and trust, helpful, humanistic, partnership communication (Zeer, 1999; Zyazyun, 2008; Ogienko, 2014). Facilitation is also a process that takes place in conditions of human interaction and aims at creating the atmosphere of goodwill, trust, openness, self-development, self-improvement of each individual.

Pedagogical action in facilitative interaction. Pedagogical action in facilitative interaction is focused on assistance, creation of a situation of success, focus on the learner, his or her inner world, experiences and emotions. Therefore, the conditions of facilitation are: problem-oriented approach to learning, teacher's deep trust in the learners, their capabilities, the respect and tolerance to learners, understanding of their behavior, provision of learners with informative, educational, technical and material resources (Ogienko \& Terokhina, 2014). The basic principles which constitute the foundations of pedagogical actions in facilitative interaction are the principles of the active participation of the learner, involvement, shared responsibility, self-presentation (Avdyeyeva, 2005).

For understanding the structural and functional nature of the pedagogical action we use the definition made by I. Zyazyun (2008): “teacher's command of the learning content and educational techniques and skills of translating this content into different types of students' experience" (p. 15). To comprehend the process of facilitative interaction we consider it appropriate to draw on the concept of facilitation, which is based on the andragogical, synergic, axiological and acmeological approaches. Its essence lies in initiating the teacher's self-actualization due to provision of the leading 
role of activities, development of consciousness, independence, freedom of choice in the reproduction of the new knowledge, personal and professional growth. According to this concept, the algorithm of the teacher's educational actions is represented as an "Attribution ring":

- facilitation of motivation activities;

- facilitation of goal setting;

- facilitation of search of the subject of knowledge;

- facilitation of search of learning methods;

- facilitation of search of means of knowledge acquisition;

- facilitation of realization of the learning process;

- facilitation of reflection (Dymukhametov, 2004).

Thus, facilitation puts forward certain requirements to the pedagogical action based on the assumption that stimulation, initiation, promotion, self-improvement and self-education of learners should take place due to a special style of the teacher, characteristics of his or her personality. Thus, the pedagogical actions of the facilitator are aimed at creating favorable conditions for self-directed and meaningful learning.

Teacher as facilitator. According to C. Rogers (1994), there are three main attitudes of the facilitator that can be considered as important psychological factors of his or her pedagogical action. The first one involves openness of the teacher to his or her own opinions and feelings, the ability to openly express them in the interpersonal communication with learners. The second attitude is characterized by "acceptance" and "trust", which is the inner confidence of the teacher in abilities and potential of each student. The third attitude is described by the term "empathic understanding" which is the teacher's vision of each student's inner world and behavior from a perspective of the student, as if viewed through his eyes.

C. Rogers (1994) believes that while communicating with students the facilitator should be able to "stand in other people's shoes", to view the world and himself through the students' eyes (p. 25).

Empathy (comes from Greek) involves understanding relationships, feelings and psychological states of other people in the form of compassion. C. Rogers (1994) argues that empathy is not a state, but a process, special relationships which include several aspects: entry into the inner world of feelings of another person; sensitivity to changing processes that happen in this world, living "the life of another person" - politely, in a non-judgmental way, not trying to open more than this person is ready to show, but helping him or her make the experience more complete.

Empathic pedagogical action, by I. Zyazyun's (2008) definition, is a special teacher activity, which is manifested as an emotional contact with the student and a structure that contains all empathic components. "Psychological infection" occurs during an empathic pedagogical action when the teacher transfers his or her emotional state to learners.

Psychological factors of facilitative activities. We found that psychological factors which impact the efficiency of the pedagogical action in facilitative interactions are: the importance of learning for learners, congruence of the teacher, psychological safety and psychological freedom, creation of conditions for facilitative communication.

According to the sources we analyzed and our own teaching experience, only meaningful learning is the most efficient, as it does not involve reproductive learning, but changes the internal sensory-cognitive experience of the learner.

Congruence of the teacher is expressed by the awareness of his relationship to people he works with. He reflects about the interaction, understands and accepts his own feelings towards learners and their environment, which makes it possible for him to be honest in relations with learners. If congruent, people in the process of communication inevitably express their true feelings and emotions, not facts about other people or the outside world (Rogers, 1994, p. 104).

Psychological security is achieved during facilitation due to the recognition of the value of an individual and the creation of conditions where no external evaluation is present. The teacher provides conditions for the development and fosters the creativity of the learners. At the same time, psychological safety creates conditions for psychological freedom, which involves the formation of learners' creativity and self-expression (Tassou, 2009). 
The research shows that educational facilitation increases the effectiveness of education and development of the participants of the educational process owing to facilitative communication investigated by V. Kan-Kalyk, S. Kolomyychenko, I. Kulikova, O. Vrublevska, I. Zymnya and others. The facilitative communication is primarily regarded as an inherent feature of the teacher's personality that develops and enables pedagogical action inspiring and encouraging the learner to the intense conscious self-transformation for the achievement of the highest priority personal meanings of life, thus actualizing the process of his efficient self-development (Vrublevskaya, 2005).

From C. Rogers' (1994) point of view, learning can be effective if the teacher builds the relationships with learners that facilitate the learning process, thus removing all possible barriers in relations, actualizing the learner's desire to learn (p. 106). He believes that free and creative learning process is the purpose of education, therefore, facilitative foundation of relations between the participants of the learning activity meets the need of individuals to be their own selves in a dynamic society.

Facilitative communication should be considered, firstly, as free communication which involves a combination of existing and potential freedom, spiritual openness of the participants of communication; secondly, - as creative communication which requires individual creativity, allowing the person to move forward in self-actualization; thirdly, - as a reflexive communication, which actualizes the need of an individual for self-analysis, self-identification, self-determination. At the same time, the formation of the facilitative communication is the personal movement ahead and selfdevelopment of the teacher, a process of practical change and self-improvement of his personality.

The facilitative influence is of great importance as it produces a stimulating effect of the teacher's activity on the learner, making the latter more active and motivated. Among the pedagogical actions which produce such influence are approval, encouragement, creation of a situation of success and others. Their effectiveness is influenced by the development of such personal characteristic of the teacher as the ability to be a facilitator. The main parameters of this characteristic are: empathy as understanding of the emotional state of another person; communicativeness and sincerity, congruent self-expression; attractiveness as human desire for a positive attitude from other people, based on the person's own positive attitude to these people; tolerance as the ability of non-judgmental perception of opinions and ideas of other people, patient attitude to them; leadership as a process of influence on other people in the process of their cooperation; credibility; self-confidence as comprehensive sense of trust in one's abilities.

Conclusion. Pedagogical facilitation is an innovative approach to teaching which promotes interest, cognitive activity, self-comprehension of the learner, realization of personally meaningful goals in learning and setting up the creative learning environment. Pedagogical facilitation is focused not only on assistance, creation of a situation of success, concetration on the learner, his inner world, creation of psychological climate of trust; ensuring cooperation; actualization of motivational learning resources, but also on the teacher's personal and professional growth and self-development. Pedagogical action in facilitative interaction is determined by the psychological safety and psychological freedom, creation of conditions for facilitative influence, as also by the pedagogical empathy of the teacher, his professional and communicative competence, congruence.

The importance and urgency of the problem determine the necessity for further study. The issues of formation of future teachers' facilitative competence, the mechanisms of facilitative interaction require further research.

\section{References:}

Avdyeyeva, I. M. (2005). Pryntsypy pedahohichnoyi fasylitatsiyi [Principles of pedagogical facilitation]. Naukovi zapysky Instytutu psykholohiyi imeni H.S. Kostyuka APN Ukrayiny, 26, 24-28.

Dymukhametov, R. S. (2004). Nauchno-metodycheskoe obespechenye povyshenyya kvalyfykatsyy pedahohov [Scientific and methodological support of continuing education of teachers]. Chelyabynsk, Russia: ATOKSO.

Halitsan, O.A. (2009). Sutnist i struktura pedahohichnoyi fasylitatsiyi vchytelya [The essence and structure of pedagogical facilitation of the teacher]. Narodna osvita, 3(9). Retrieved March 22, 2016, from: http://www.nbuv.gov.ua/ejournals/NarOsv/2009-3/9goapfv.htm

Ogienko, O. \& Terokhina, N. (2014). The American experience of preparation of adult educators. Euro-American Scientific Cooperation, 7, 51-54. 
Ogienko, O.I. (2014). Teoretychni zasady innovatsiynoyi pedahohichnoyi osvity [Theoretical foundation of innovative teacher education]. Suchasni informatsiyni tekhnolohiyi ta innovatsiyni metodyky navchannya u pidhotovtsi fakhivtsiv: metodolohiya, teoriya, dosvid, problemy, 37, 147-151.

Rogers, C. (1994). Freedom to Learn ( $3^{\text {rd }}$ ed.). New York, USA: Pearson.

Schutte, M. (2015). Facilitation Practice (Adult Education, Training and Development Book 2). Raleigh, NC: Future Performance Training.

Tassou, M. (2009). Creative Facilitation. Delft, Netherlands: VSSD.

Vrublevskaya, E.H. (2005). Razvytye sposobnosty pedahohov $k$ fasylytyruyushchemu obshchenyyu [Development of teachers' ability to facilitative communication]. Khabarovsk, Russia: Znanye.

Zeer, É. F. (1999). Psykholohycheskye osobennosty pedahohycheskoy fasylytatsyy [Psychological characteristics of pedagogical facilitation]. Obrazovanye y nauka, 2(2), 26-34.

Zyazyun, I.A. (2008). Filosofiya pedahohichnoyi diyi [Philosophy of pedagogical action]. Cherkasy, Ukraine: Vydavnychyi viddil CHNU im. Bohdana Khmelnytskoho.

Zyazyun, I.A., Kramushchenko, L.V., \& Kryvonos, I.F. (2008). Pedahohichna maysternist [Pedagogical competence]. Kyiv, Ukraine: SPD Bohdanova. 